\title{
The Devilish Complexities of Divine Simplicity
}

Of all the core doctrines of traditional Western theology, perhaps none has received more summary dismissals than the doctrine of divine simplicity. Consider, for example, the throwaway remark made by Paul Fitzgerald (1985:262) in his discussion of the views of Eleanor Stump and Norman Kretzmann on issues concerning divine eternity:

This feature of eternality may be impossible to reconcile with the divine simplicity. But that doctrine never had much to recommend it anyhow. (My emphasis.)

Fitzgerald's attitude towards the doctrine of divine simplicity is quite widespread, and is shared by many who are not otherwise particularly ill-disposed towards traditional Western theology. Even those who are far better disposed towards traditional Western theology are usually prepared to concede that the doctrine is hard to understand, let alone to accept. Thus, for example, at the beginning of her entry on simplicity in the Blackwell Companion to Philosophy of Religion, Eleanor Stump (1997:250) writes:

Among the traditionally recognised divine attributes regularly discussed by medieval theologians and accepted by them as part of orthodox religious belief, the strangest and hardest to understand is simplicity. (My emphasis.)

Given the nature of his book, it should come as no surprise that Richard Gale (1991) gives pretty short shrift to the doctrine of divine simplicity. Taking into account his delight in philosophical combat, it seems appropriate to use this occasion to try to defend the apparently indefensible (and not only from Gale's attack on it, though that shall serve as our paradigm).

I shall begin with Gale's explanation of the doctrine, and his reasons for dismissing it. I shall then go on to suggest an alternative understanding of the view which seems to me to avoid the difficulties which Gale and other contemporary philosophers have raised. I shall not be claiming that my "alternative understanding” is what traditional theologians had in mind; however, I do want to claim that my "rational reconstruction" has many of the properties which those theologians wanted the doctrine to have.

Of course, in undertaking to defend the doctrine, I am not undertaking to defend its truth; I'm not a theist so, a fortiori, I think that the doctrine is false. What I do want to defend is the rational acceptability of the doctrine: given that you buy Western theism in general, there is a coherent—albeit controversial—doctrine concerning divine simplicity which is also available to you. ${ }^{1}$

\footnotetext{
${ }^{1}$ Actually, the claim in the text probably overstates things a little. What I shall really argue for is the claim that the doctrine of divine simplicity is hardly in worse standing than some currently popular theories about truthmakers and the truthmaking relation. If you hold that these theories are rationally unacceptable, then I shall not give you any reason to suppose that the doctrine of divine simplicity is rationally acceptable.
} 
Gale (1991:23f.) presents the doctrine of divine simplicity in the following way: If God is an absolutely perfect being, then (1) God's existence cannot be dependent upon anything else, and (2) there can be no distinctions within God's nature.

According to Gale, (1) entails that God does not instantiate any properties-since, if God did do this, God would be distinct from, and hence dependent upon, those properties. Furthermore, according to Gale, (2) entails that there is no distinction between God's properties-God's omnipotence is identical with God's omniscience, which is identical with God's omnibenevolence, and so on. Most of Gale's subsequent discussion focuses on the alleged consequence of (2), which we seem to be invited to think of as the doctrine of divine simplicity proper.

However, before we turn to that discussion, it seems worth noting that the way in which Gale sets up the view is obviously unhappy. On the one hand, according to Gale, (2) presupposes that God has properties: in effect, it says that God has exactly one property. On the other hand, according to Gale, (1) entails that God does not have properties: Gale says explicitly that it follows from (1) that God "does not instantiate any properties”. So, on Gale's understanding of (1) and (2), it seems that one cannot consistently endorse them both: something has to go.

Clearly enough, Gale's implicit assumption is that (1) must go: it is simply absurd to suppose that God has no properties. Given that that view is simply absurd, the only claim worth discussing in the context of the question of divine simplicity is the view that God has exactly one property. We shall return to reconsider this matter after we rehearse the objections which Gale makes to the idea that God has exactly one property.

According to Gale, how one analyses the claim that God has exactly one property turns on how one chooses to interpret the word "property". On the one hand, the claim could be that God is a single property-instance; on the other hand, the claim could be that God is a single property. Neither of these views is particularly attractive.

However, before we get to objections to them, it is worth noting some further slippage in Gale's discussion: it is one question whether God has only one property; it is another question whether God is a single property. The formula which says that God's omnipotence is identical with God's omniscience, which is identical with God's omnibenevolence, and so forth, does not entail that God is that one property; rather, it entails no more than that God has only one property.

A plausible conjecture about what is doing the work here might be derived from Gale's gloss on (2), i.e. from Gale's gloss on the claim that there can be no distinctions within God's nature: "were there any compositeness in God's nature, he would face the possibility of destruction through decomposition". I suspect that what Gale takes to justify the move from God has only one property to God is a single 
property is the thought that if God has a property and yet is not identical to that property, then there is some "compositeness" in God (and hence there is "the possibility of destruction through decomposition”).

This conjecture is at best plausible; it is not clearly supported by the text. What Gale explicitly discusses is what would follow if there were compositeness in God's nature; but what licenses the inference which I am discussing is what would follow if there were compositeness in God. If there is a distinction between God's nature and God, then we still do not have even a prima facie justification for the move from God has only one property to God is a single property. Perhaps it is part of the doctrine of divine simplicity — or, at any rate, of familiar modern presentations of that doctrinethat there is no distinction between God, God's existence, and God's nature; but, at the very least, this claim requires some examination in the context of Gale's discussion.

Moreover, even if we accept that the requirement that there be no distinctions in God's nature licenses the move from God has only one property to God is a single property, it is not clear that the justification which Gale offers for the requirement is up to the job. Even if there are "distinctions in God” or "distinctions in God's nature", it is far from obvious that it follows that God "faces the possibility of destruction through decomposition”. Of course, if this worry is well-founded, it is not a problem for Gale; rather, it is a problem for motivating the view which he takes to be the traditional doctrine of divine simplicity. However, since the idea, that there can be internal or necessary relations between properties, is such a familiar one, there is some reason to take this motivational difficulty as a reason for suspecting that we still have not arrived at a satisfactory characterisation of the doctrine of divine simplicity. (We shall return to this issue in section 4.)

1. Against the claim that God is a single property, Gale offers four objections. First, the identification of God with an abstract entity makes God conceptually unfit to be the personal creator of the universe; in particular, an abstract entity cannot be a causal agent. Second, the identification of God with a property has the unwanted consequence that no individual other than God can have any of God's properties; for surely God must be a person, be self-identical, be an entity, and so forth. Third, it is just obvious that the properties identified in the crucial formulaomnipotence, omniscience, omnibenevolence, and so forth-are different: the words "omnipotence”, “omniscience”, “omnibenevolence” plainly differ in sense, and yet the sense of each is just the property which it expresses. Fourth, since it is obvious that, say, power and benevolence differ, there is good reason to think: (a) that increasing degrees of power and benevolence differ; and hence (b) that unlimited degrees of power and benevolence-i.e. omnipotence and omnibenevolence-also differ.

2. Against the claim that God is a single property instance, Gale offers two objections. First, he claims that the identification of God with God's instancing some property doesn't really satisfy the intuitive desiderata for the doctrine of 
divine simplicity: on this approach, it will still be the case that God instantiates properties, and hence is dependent upon them. Second, the last of the considerations given in the previous case still applies: we have very good reasons to think that instances of omnipotence must be distinct from instances of omnibenevolence (notwithstanding considerations urged by Stump and Kretzmann on behalf of the contrary view).

3. Against the suggestion — attributed to William Mann—-that God's properties are causal powers which are identical to God's instancing of them, Gale offers three objections. First, he claims that, as in the previous case, the identification of God with God's instancing some property doesn't really satisfy the intuitive desiderata for the doctrine of divine simplicity: on this approach, it will still be the case that God instantiates properties, and hence is dependent on them. Second, if it were true that properties are identical with their instancing in objects then, since properties are abstract entities, it will still follow that God is conceptually unfit to be the creator of the universe. Third, the last of the considerations urged in the previous two cases still applies: we have very good reasons to think that instances of omnipotence must be distinct from instances of omnibenevolence, whether or not these are taken to be causal powers.

In my view, the force of these objections varies considerably: some seem cogent, but others are plainly highly controversial. First, the strengths. It does seem to me that taking God to be a property, or a property-instance, or a causal power, wrongly places God in an inappropriate ontological category. Moreover, it seems to me that there are plainly good reasons for thinking that omnipotence and omniscience are distinct properties, if they are properties at all (and likewise for the corresponding claims about property-instances and causal powers). No doubt there is room for discussion of the details of Gale's arguments on these points; but there is no reason for me to pursue those considerations here.

Now, the weaknesses. First, Gale's discussion makes certain assumptions about the nature of properties which no defender of the doctrine of divine simplicity should grant. Gale simply assumes without argument that properties are the ontological shadows of meaningful predicates: properties are the senses of predicates, and even predicates like "is an entity”, "is identical to" and 'is a person” express properties. Whether or not we add to this the assumption that entities are the ontological shadows of meaningful names, we shall very quickly get out the conclusion that, if God exists, then God has many distinct properties. (God is a person. God is self-identical. God is an entity. Etc. So the fussing about whether God's omnipotence is identical to God's omniscience, etc. then seems to be completely beside the point.) Second, Gale's discussion seems to be based on the assumption that the "property-instance" variant of the view has to hold that God is identical with his instancing of certain properties. However, on the one hand, that way of formulating the view seems to be at best of dubious coherence, since it seems to require that God is both that which instances the properties and the instancing of the properties; and, on the other hand, it seems far more natural to suppose that the view in question holds that God is identical to a trope, i.e. to what is sometimes called an "abstract particular".

Of these considerations, the first is far more important (at least for my present purposes). It seems evident that, if one were to try to defend the view that God is only 
one property, or that God has only one property, then one would have to assume that there are many predicates which fail to express properties, even though atomic sentences in which those predicates feature are true. But Gale's discussion is largely based on the assumption that, if one were to try to defend the view that God is only one property, or that God has only one property, then one would have to assume that there are many predicates with distinct senses which nonetheless express the same properties. Of course, Gale is aided in this assumption by the work of the theists whom he discusses: for example, Stump and Kretzmann aim to show that God's omnipotence is the very same property as God's omniscience, even though the expressions "God's omnipotence" and "God's omniscience” have very different senses. Since this brings us to the core of my alternative interpretation of the doctrine of divine simplicity, I shall now move to sketch that interpretation.

(Perhaps it is worth noting, before we conclude this section, that there are many independent reasons for thinking that one could not combine the view that God has exactly one property with a generous conception of properties and property individuation. Consider the predicate “...possesses exactly one property”. Does this predicate express a property? If so, then we seem to have the makings of a proof that nothing can possess exactly one property, and perhaps even of a proof that anything at all will have infinitely many properties. (Suppose that a has the property F. Then it also has the property of having at least one property (where this second property is distinct from F). So it also has the property of having at least two properties (where this third property is distinct from $\mathrm{F}$, and from the property of having at least one property). And so on.) If you allow that necessary extension suffices for property identity — and that is a highly contentious concession — you might be able to contest this argument; but, at the very least, the matter is surely not straightforward.))

The core of my alternative interpretation is the thought that, while God is a truthmaker for all of the true claims of the form "God is F", it does not follow from this that there is a property which corresponds to the predicate " $F$ " which is possessed by God. ${ }^{2}$ Provided that we deny that all predicates express properties—or, perhaps, that we deny that all successful singular terms denote objects-we may suppose that many sentences of the form "Fa" which are true are not made true by the possession on the part of the referent of "a" of the property which is expressed by the predicate "F".

One familiar paradigm for the kind of view which I have in mind is the realism about universals which is defended by David Armstrong (1978) (1997). On this view, immanent universals are part of the furniture of the universe; but it is up to science to determine what these immanent universals are, and the guide which is provided by

\footnotetext{
${ }^{2}$ Anyone who accepts the thought in question is likely to accept the further thought that God is the minimal truthmaker for each of these true claims. For discussion of truthmaker theory, see, for example: Bigelow (1988), Fox (1986), Heil (forthcoming), Mulligan et. al. (1984), Oliver (1996), and Restall (1996). Further details about the nature of the theory-e.g. whether it is or is not committed to the existence of minimal truthmakers in every case-are not relevant for the purposes of the present discussion.
} 
natural language is shaky at best. That a sentence of the form "a is red" is true does not entail that there is a property of redness which is expressed by the predicate "... is red"; rather, what it entails is that there is some suitable constellation of universals which somehow together contrive to make it the case that the sentence is true. That a sentence of the form "a exists" or "a is self-identical” is true does not entail that there are properties of existence and self-identity which are expressed by the predicates “... exists" and "... is self-identical”; rather, these sentences are made true simply by the object which is the referent of the singular term "a". That two sentences of the form "a is red" and "b is red" are both true does not entail that there is some universal which plays a role in making both of these sentences true; it is possible that none of the universals which play a role in making true the sentence "a is red" have any role to play in making true the sentence "b is red". (This point is supported by those lines of thought which suggest that, from a scientific standpoint, "redness" constitutes a highly gerrymandered and heterogenous “kind”.)

In order to develop an account of divine simplicity, a natural thought is that we might seize upon some of the general features of Armstrong's view. Suppose that it is not the case that every predicate which features in true atomic sentences expresses a property. Suppose, more generally, that the nature of the reality which makes true sentences true does not have a structure which is reflected in the grammatical structure of the sentences which are made true. Then, holding that sentences of the form "God is F" are true does not require us to suppose that there is some property which corresponds to the predicate "F" which is possessed by God and which contributes to making the sentence in question true. So, we can say, on the one hand, that God is omnipotent, omniscient, and all the rest-and we can mean what we say in a straightforward literal sense; and, we can also say, on the other hand, that God has no parts and that there are no categorial distinctions to be drawn in the case of God. We can say that God is the truthmaker for the claim that God exists, that God is selfidentical, that God has no parts, that God is not a property, that God is not an entity, that the ontological category to which God belongs is sui generis, and so forth. Moreover, we can say that God is also the truthmaker for the claim that God is omnipotent, that God is omniscient, that God is omnibenevolent, and so on. And we can say that God is the truthmaker for the claim that God is powerful, that God is good, that God knows some things, and so forth.

What assumptions do we need to make in order to support this approach? I think that we shall need to suppose that there are no predicates that express universals which apply to God and to other entities. So, for example, since “... is powerful” applies both to God and to other entities, we shall need to suppose that there is no universal of powerfulness. But that seems plausible enough: when sentences of the form "a is powerful" are true, this is doubtless because there are truthmakers involving members of metaphysically fundamental categories which somehow combine to make these sentences true. Of course, in the case of God, we are also supposing that God does not instantiate universals; so we need the further supposition that the metaphysically fundamental categories which somehow combine to make these sentences true are heterogeneous. However, once we have granted the other elements of the kind of truthmaker theory which is here envisaged, it is not clear that this further supposition is out of the question. If "redness" can be metaphysically gerrymandered and heterogeneous, then why shouldn't any “properties” which are shared by God and other entities also be like this? 
Plainly, there are many questions which might be raised about the suggestion which I made in the previous section. I shall try to address some of the more obvious questions here.

1. One strand of traditional theological thought which seems to me to be related to the doctrine of divine simplicity is typically expressed in claims about limits to our ability to understand God. Sometimes, it is said that we can make no true positive claims about God. (I associate this claim with the label "negative theology".) Sometimes, it is said that we can only speak in an analogical or metaphorical fashion about God: while we speak truly when we say, for example, that God is powerful, we are here involved in the irreducible use of analogy, or metaphor, or the like; we cannot provide a literal equivalent for the claim which is here expressed in analogical fashion. Sometimes, it is said that we can only speak in an equivocal fashion about God: while we speak truly when we say, for example, that God is wise, we must not suppose that the sense of the predicate “... is wise" is the same in its application to God as it is in its application to other creatures, such as human beings. (I associate these latter two claims with the label “analogical predication”.)

The account which I have given of divine simplicity provides a way of understanding all of these claims. On the one hand, there is a sense in which all of these traditional claims are false: we can make true positive claims about God; we can make true literal claims about God; and we can apply predicates to God which have exactly the same sense which they have when they are applied to other creatures. However, on the other hand, we must not suppose that when we say something which is literally true of God, that we can read off the ontological structure of that which makes the sentence true from the surface syntactic form of the sentence in question; and nor should we think that there is any other sentence which we could use instead for which it would be true that we could read off the ontological structure of that which makes the sentence true from the surface syntactic form of the sentence in question. Thus, there is a good sense in which the spirit of all of the traditional claims is preserved under my suggestion; and, moreover, that this preservation does not come at the high price of engaging in double-think, or double-talk, or the like.

The model afforded by Armstrong's treatment of “... is red” should be borne in mind here. The doctrine of divine simplicity belongs to a philosophical theory which greatly predates the linguistic turn and the consequent deflationary approach to metaphysics which supposes that basic metaphysical categories must be mirrored in the surface syntax of canonical notation. Attempts to discuss the doctrine while also making using of pleonastic conceptions of properties, objects, states of affairs, and the like, seem to me to be bound to end in disaster. Of course, friends of the linguistic turn and deflationary metaphysics may well conclude that this is bad news for the doctrine of divine simplicity; however, it does seem to me to advance understanding of the issues involved to cast them in this kind of light. 
2. Perhaps the most apparently intractable problem for the doctrine of divine simplicity concerns the treatment of contingent truths about God. Suppose, for example, that we want to hold that, while God does choose to answer a particular prayer, it is possible for God to choose not to answer that prayer. Consider our world, in which God does choose to answer the prayer in question, and a world which is as much like ours as possible, save for the fact that in that world God chooses not to answer the prayer. Given that the sentence "God chooses to answer this prayer" is true in our world, but not in the other world, it is natural to think that there must be a truthmaker for the claim in our world which is not present in the other world. But, on the view which has been put forward, it may seem impossible to explain how this can be the case. In our world, God (perhaps together with some other "things") is the truthmaker for the sentence "God chooses to answer this prayer"; in the other world, God (perhaps together with some other "things") is the truthmaker for the sentence "God chooses not to answer this prayer". Unless there is some relevant difference between God in our world and God in the other world, there is no prospect of maintaining the view. But, if there is a difference between God in our world and God in the other world, then - contrary to the doctrine of divine simplicity — there must be parts, or respects, or whatever, of God which vary between the worlds.

One response to this question-which many traditional theologians at least countenanced as a possible reply - is to deny that there is any contingency in God. If God chooses to answer a given prayer in our world, then there is no world in which God chooses not to answer that prayer. This line of response has severe implications for freedom — both human and divine-and might well be considered too high a price to pay for the doctrine of divine simplicity. But what other options do we have?

I think that the right way to respond is to deny the claim that, if God chooses to answer a given prayer in one world, and chooses not to answer it in another world, then there must be parts, or respects, or whatever, of God which vary between the worlds. In our world, God (perhaps together with some other "things") is the truthmaker for the claim that God chooses to answer the prayer; in the other world, God (perhaps together with some other "things") is the truthmaker for the claim that God does not choose to answer the prayer. Perhaps the truthmaking relation is itself contingent ${ }^{3}$; perhaps God can differ between the two worlds even though there is no part, or respect, or whatever, of God which differs between the two worlds"; perhaps the truthmakers for the sentence "God chooses to answer the prayer" involve things other than God which do vary between the two worlds ${ }^{5}$; or

\footnotetext{
${ }^{3}$ Josh Parsons has ably defended the tenability of the denial of what he calls "truthmaker essentialism" (in his doctoral dissertation and elsewhere); this denial is just the claim which is countenanced in the text. See, for example, Parsons (1999).

${ }^{4}$ Given that we are supposing that God is metaphysically sui generis, and, in particular, that we are supposing that there is no complexity or composition of any kind in God, it is not clear that we are stretching things any further if we suppose that there can be brute differences across worlds in the case of God, i.e. differences which are not a difference in parts, or respects, or whatever. Granted, this sounds odd; but it is not clear that it is in any odder than everything else which is tied up in the doctrine of divine simplicity.

${ }^{5}$ This line may seem to fly in the face of the intuition that the property of choosing to do such-andsuch is an intrinsic property of the chooser, and hence something which is made true entirely by how
} 
perhaps there is some other explanation of how this can be. There are enough options available that there is clearly quite a bit of room in which to manoeuvre.

3. Much of the recent-and not-so-recent-discussion of doctrines of divine simplicity has focussed on questions about the identification of properties-e.g. When is F-ness identical to G-ness? When is the F-ness of $x$ identical to the Gness of $x$ ? and so on-and on questions about the identification of God with a property, or a property instance, or a causal power, or the like-e.g. Is God identical to F-ness? Is God identical to his F-ness? Is God identical to his instancing the property of F-ness?, and so forth. Given the importance that discussion of these kinds of questions has in the theological tradition, it might be claimed that my suggestion - which holds that these questions either admit of straightforward negative answers (in the case of the latter category), or else are irrelevant to the doctrine of divine simplicity (in the case of the former category) — must involve some kind of misunderstanding. Augustine, Anselm, Aquinas, and many others ${ }^{6}$, seem to be agreed that the doctrine of divine simplicity requires the identification of God with a property, or a property instance, or a causal power, or the like; and this agreement, in turn, seems to require that consideration be given to questions about the identification of properties. So whom am I to say otherwise?

I take it that the core of the doctrine of divine simplicity is—as Stump (1997:250) says - that "God is one in a radical kind of way: a simple God lacks composition of any kind”. Moreover—as Stump (1997:250) continues-I agree that it follows from this core claim: (1) that God has no spatial or temporal parts; (2) that God has no intrinsic accidental properties; (3) that there is no "real" distinction between essential properties in God's nature; and (4) that there is no "real" distinction between essence and existence in God. However, I think that the reason why (1)-(4) follow from the core claim is that only a being which has no properties can lack composition of any kind; hence, of course, God has no spatial or temporal properties, no intrinsic accidental properties, no essential properties, and no essence or nature. Once we take on board the key neo-Platonist intuition about God, we should give up on the idea of applying the key categories of Aristotelian metaphysics to God: the result is bound to be a conceptual mess. Of course, I haven't proved that the result is bound to be a conceptual mess. ${ }^{7}$

things are with the chooser, and not at all by how things are with other things. However, if we are supposing that there is no universal which is expressed by predicates of the form “... chooses to do such-and such”, then it is not clear that we are any longer entitled to the intuition. Again, there is something here which looks odd; but it is not clear that it is in any odder than everything else which is tied up in the doctrine of divine simplicity.

${ }^{6}$ For recent discussions which takes these issues seriously, see, for example: Bennett (1969), Burns (1989), Dewan (1989), Hughes (1989), Hughes (1995), La Croix (1977) (1979), Lamont (1997), Leftow (1990), Mann (1975) (1982) (1983) (1986), Miller (1994), Morris (1984) (1985) (1988), Plantinga (1980), Rogers (1996), Stump (1997), Stump and Kretzmann (1985) (1987), Vallicella (1992) (1994), Wainwright (1979) and Wolterstorff (1991).

${ }^{7}$ Consider, for example, Stump (1997:251): "God is so radically one that there is no composition in him even of essence and existence. Consequently, God does not have an essence; instead, he is identical with his essence, and even his existence cannot be distinguished from that essence." This is surely incoherent: on the one hand, we are told that God has no essence; on the other hand, we are told that God's essence- - the thing whose existence has just been denied!-is identical to God's existence. This pattern — of claiming to identify things which one elsewhere says do not exist-is characteristic of much of the literature on divine simplicity. 
However, I think that a quick look at the historical record provides ample support for this claim. Alternative ways of understanding the claim that God lacks composition of any kind are clearly worth serious consideration if they manage to avoid the difficulties which have beset traditional explanations of this doctrine.

4. I expect that some philosophers will want to object that I haven't really succeeded in producing a defensible version of the doctrine of divine simplicity because I haven't explained how anyone could come to have reason to accept the doctrine in the form which I have given to it. What reason could one have for believing that God has no properties; come to that, what reason could have for believing that it even makes sense to suppose that God has no properties?

Well, let's see. It is fairly uncontroversial that the doctrine of divine simplicity requires that God is not dependent upon anything, that God has no parts, that there are no distinctions in God, and so forth. The principal challenge which the doctrine affords is how to reconcile these claims with further claims about God which believers standardly suppose to be true, e.g. that God is wise, sympathetic, responsive to prayer, and so forth. The standard philosophical response has been to claim that God belongs to an unexpected but standard ontological category: God is a property, or a property-instance, or a self-instancing property, or the like. However, this standard kind of response surely goes too far in specifying the ontological category to which God belongs. Far better to say that God is metaphysically sui generis, and that there is nothing further to be said about the ontological category to which God belongs. With the standard reply, we can say that there is a single truthmaker which makes a diverse range of sentences true; but we don't need to say any of the manifestly bizarre sounding things which proponents of the standard response also say. After all, it is no easier to understand how a property-instance could be a truthmaker for familiar claims about God than it is to understand how something which is metaphysically sui generis is a truthmaker for those claims.

But how does all of this answer the charge that it makes no sense to suppose that God has no properties? And isn't that very claim as bizarre sounding as any of the claims which belong to the standard response? Well, remember that the claim that God has no properties is to be understood in the following way: it is not the case that God shares the same metaphysical structure as other "things", which are somehow constituted from universals (and perhaps other metaphysically primitive materials, such as bare particulars, and the like). God differs from other "things" in not having metaphysical composition of this (or any other) kind. But, given that we accept something like Armstrong's views about the truthmaking relation, there are no further mysteries or bizarre stipulations which are required in order to make sense of divine simplicity: we are already committed to the view that the surface syntax of true sentences is no decent guide to the metaphysical structure of the truthmakers for those sentences. And there is no reason to suppose that our knowledge that certain sentences express truths requires us to have detailed knowledge of how it is that the truthmakers conspire to make the sentences in question true. (Again, recall the way that Armstrong treats sentences of the form "a is red".) We can know that God is wise without having any insight into God's metaphysical constitution, i.e. without having any knowledge about how the claim that God is wise is made true. 
Perhaps it will be said that this is still a sticking point: what sense does it make to suppose that we can know that certain sentences are true when we are also forced to say that we have-and can have-no knowledge about how the truthmakers for those sentences make those sentences true? Perhaps this is a sticking point. Certainly, it seems to me to mark a divide between those philosophers who take the "linguistic turn", and those who do not; however, if this is an important sticking point, then it is surely useful to have recognised that it is the key point on which doctrines of divine simplicity stand or fall. (It seems to me to be consonant with longstanding theological tradition to suppose that we can have no insight into the "nature" of God, and yet that we can make many claims about God which are literally true. I don't know of any way of making sense of this tradition other than to take the line on truthmaking which I have taken in this paper.)

\section{References}

Armstrong, D. (1978) Universals and Scientific Realism, 2 Volumes, Cambridge: CUP

Armstrong, D. (1997) A World of States of Affairs Cambridge: CUP

Bennett, D. (1969) “The Divine Simplicity” Journal of Philosophy 66, 628-37

Bigelow, J. (1988) The Reality of Numbers Oxford: Clarendon

Burns, R. (1989) “The Divine Simplicity in Thomas Aquinas” Religious Studies 25, 3, 271-93

Dewan, L. (1989) "Saint Thomas, Alvin Plantinga, and the Divine Simplicity" Modern Schoolman 66, 141-51

Fitzgerald, P. (1985) "Stump and Kretzmann on Time and Eternity” Journal of Philosophy 82, 5, 260-9

Fox, J. (1986) “Truthmaker” Australasian Journal of Philosophy 65, 188-207

Gale, R. (1991) On the Nature and Existence of God Cambridge: CUP

Heil, J. (forthcoming) "Language, Thought and Reality”, ms.

Hughes, C. (1989) On a Complex Theory of a Simple God Ithaca: Cornell University Press

Hughes, G. (1995) The Nature of God London: Routledge

La Croix, R. (1977) “Augustine on the Simplicity of God” New Scholasticism 51, 4, 453-69

La Croix, R. (1979) “Wainwright, Augustine and God's Simplicity: A Final Word” New Scholasticism 53, 1, 124-7

Lamont, J. (1997) “Aquinas on Divine Simplicity” Monist 80, 4, 521-38

Leftow, B. (1990) “Is God an Abstract Object?” Nous, 24, 4, 581-98

Mann, W. (1975) “The Divine Attributes” American Philosophical Quarterly 12, 2, 151-59

Mann, W. (1982) “Divine Simplicity” Religious Studies 18, 451-471

Mann, W. (1983) "Simplicity and Immutability in God” International Philosophical Quarterly 23, 3, 267-76

Mann, W. (1986) “Simplicity and Properties: A Reply to Morris” Religious Studies 22, 343-53

Miller, B. (1994) “On 'Divine Simplicity: A New Defence”” Faith and Philosophy 11, 3, 474-7

Morris, T. (1984) “Properties, Modalities, and God” Philosophical Review 93, 1, 3555 
Morris, T. (1985) “On God and Mann: A View of Divine Simplicity” Religious Studies 21, 299-318

Morris, T. (1988) “Dependence and Divine Simplicity” International Journal for Philosophy of Religion 23, 161-74

Mulligan, K., Simons, P., and Smith, B. (1984) “Truth-Makers” Philosophy and Phenomenological Research 44, 3, 287-321

Oliver, A. (1996) “The Metaphysics of Properties” Mind 105, 417, 1-80

Parsons, J. (1999) “There is no 'Truthmaker' Argument Against Nominalism” Australasian Journal of Philosophy 77, 3, 325-34

Plantinga, A. (1980) Does God Have a Nature? Milwaukee: Marquette University Press

Restall, G. (1996) “Truthmakers, Entailment and Necessity” Australasian Journal of Philosophy 72, 331-40

Rogers, K. (1996) “The Traditional Doctrine of Divine Simplicity” Religious Studies 32, 2, 165-86

Stump, E. (1997) “Simplicity” in P. Quinn and C. Taliaferro (eds.) A Companion to Philosophy of Religion Oxford: Blackwell

Stump, E. and Kretzmann, N. (1985) “Absolute Simplicity” Faith and Philosophy 2, 4, 353-391

Stump, E. and Kretzmann, N. (1987) “Simplicity Made Plainer: A Reply to Ross' 'Absolute Simplicity”” Faith and Philosophy 4, 198-201

Vallicella, W. (1992) “Divine Simplicity: A New Defence” Faith and Philosophy 9, 4, 508-25

Vallicella, W. (1994) “On Property Self-Exemplification: Rejoinder to Miller” Faith and Philosophy 11, 3, 478-81

Wainwright, W. (1979) “Augustine on God’s Simplicity: A Reply” New Scholasticism 53, 1, 118-23

Wolterstorff, N. (1991) "Divine Simplicity” in J. Tomberlin (ed.) Philosophical Perspective 5: Philosophy of Religion Atascadero, Calif: Ridgeview 